\title{
Ammonium thiosulfate as blossom thinner in 'Maxi Gala' apple trees
}

\author{
Lucas De Ross Marchioretto(1), Andrea De Rossi(2), Micheli Fochesato Michelon ${ }^{(1)}$, \\ Julio Cesar Orlandi(1) and Leonardo Oliboni do Amaral(1)
}

\begin{abstract}
(1)Universidade do Estado de Santa Catarina, Avenida Luiz de Camões, no 2.090, Conta Dinheiro, CEP 88520-000 Lages, SC, Brazil. E-mail: lucasdeross@hotmail.com, mickefmichelon@hotmail.com, julioorlandi23@yahoo.com.br, loamaral@ucs.br(2)Embrapa Uva e Vinho, BR-285, s/nº, CEP 95200-000 Vacaria, RS, Brazil. E-mail: andrea.rufato@embrapa.br
\end{abstract}

\begin{abstract}
The objective of this work was to evaluate the feasibility of using ammonium thiosulfate as a chemical blossom thinner in 'Maxi Gala' apple (Malus domestica) trees and its effects on fruit quality. The experiment was carried out in an experimental orchard in the Southern Brazil, in a randomized complete block design, with five replicates. Ammonium thiosulfate was sprayed on the apple trees at the full bloom stage, at $0,1.5,2.5$, and $3.5 \%$. Evaluations were performed for the effects on crop load, fruit set, yield efficiency, and fruit quality parameters such as weight, shape, total soluble solids, seed number, flesh firmness, color, and russeting occurrence. Ammonium thiosulfate at $2.5 \%$ is effective to reduce crop load and to improve fruit quality. The thinning effect of ammonium thiosulfate is not dependent on the weather conditions during the crop season. The rate of $3.5 \%$ of ammonium thiosulfate causes overthinning and does not result in the improvement of fruit quality.
\end{abstract}

Index terms: Malus domestica, ATS, blossom stage, flower thinning.

\section{Tiossulfato de amônio como raleante de floração em macieiras 'Maxi Gala'}

\begin{abstract}
Resumo - O objetivo deste trabalho foi avaliar a viabilidade de uso de tiossulfato de amônio, como raleante químico de floração, em macieiras 'Maxi Gala' (Malus domestica), e os seus efeitos sobre a qualidade dos frutos. O experimento foi realizado em pomar experimental no sul do Brasil, em delineamento de blocos ao acaso, com cinco repetições. O tiossulfato de amônio foi aplicado às macieiras em plena floração, a $0,1,5$, 2,5 e 3,5\%. Foram feitas avaliações quanto aos efeitos sobre carga de frutos, frutificação efetiva, eficiência produtiva e parâmetros de qualidade de frutos como massa, formato, sólidos solúveis totais, número de sementes, firmeza de polpa, coloração e ocorrência de "russeting". O tiossulfato de amônio a 2,5\% é efetivo na redução da carga de frutos e no aumento da qualidade dos frutos. O efeito raleante do tiossulfato de amônio não é dependente das condições climáticas durante o período de raleio. A dose de 3,5\% de tiossulfato de amônio causa raleio excessivo e não resulta em melhoria na qualidade dos frutos.
\end{abstract}

Termos para indexação: Malus domestica, ATS, plena floração, raleio de flores.

\section{Introduction}

In 2015, Southern Brazil produced 1,163,744 tons of apples on 36,089 hectares (Anuário..., 2016). Due to the usual extensive cultivated areas with apples, the labor availability, and the high-input costs, an improvement of the efficacy and efficiency of the chemical thinning is a subject requiring more research.

For apple fruit to achieve a marketable size, it is necessary to reduce up to $95 \%$ of the flowers to balance the cell division and fruit size. Blossom thinning has the greatest potential to increase fruit quality at harvest, as fruit size (weight) is highly correlated with cell numbers (Link, 2000; Lakso \& Goffinet, 2013;
Jakopic et al., 2015). Therefore, when thinning was done at blossom stage, there was a significant increase of $30 \mathrm{~g}$ in fruit weight, in comparison to thinning done at four weeks after full bloom. Additionally, flower thinning increases fruit size by $30 \%$ when it is done at flowering, in comparison to when thinning is performed after the "June drop" (Link, 2000), and improves bloom return for the following year and increases fruit total soluble solids (Meland, 2009).

The thinning effect of caustic blossom thinners are not so weather dependent as hormonal chemical thinners sprayed on fruitlets later in the season, when cloudy days and high-night temperatures in the days after spraying may lead to overthinning of fruit 
(Greene, 2002). Blossom thinners such as ammonium thiosulfate (ATS) or lime sulfur significantly decrease the rate of pollen germination or the pollen tube length, which struggles the ovule fertilization. Thereby, the fruitlet is not formed and the flower is abscised (Myra et al., 2007). At $1.5 \%$, ATS shows a strong thinning which is capable of decreasing half of the amount of flowers produced by European plums, reducing yield and fruit set more severely than hand thinning, and as a consequence, increasing the fruit weight and quality (Meland, 2007). On apple, ATS at 2\% significantly reduced fruit set and increased fruit weight (Milić et al., 2011). In the United States and Europe, the use of ATS is consolidated and there are plenty of research on this theme. In Brazil, however, little is known about the thinning properties of this caustic blossom thinner, and its effects on fruit quality.

The two hormonal chemical thinners currently registered for apple cultivation in Brazil are benzyladenine and $\mathrm{GA}_{4+7}+$ benzyladenine (Agrofit..., 2017). However, spring time in the apple producing regions is usually very unpredictable, and occurrences such as cold temperatures or cloudiness in the aftermath of spraying chemical thinners are frequent. The lack of effective options other than hormonal thinners are still one of the main discussions among apple producers. There is plenty of information about the potential use of ATS as a chemical blossom thinner in cropping systems around the world (Meland, 2007; Milić et al., 2011; Maas, 2016), and it may have potentially promising results in Brazil.

The objective of this work was to evaluate the feasibility of using ammonium thiosulfate as chemical blossom thinner in 'Maxi Gala' apple trees and its effects on fruit quality.

\section{Materials and Methods}

The experiment was carried out in the municipality of Vacaria, in the state of Rio Grande do Sul, Brazil, over two consecutive crop seasons (2015/2016 and 2016/2017), on a mature experimental orchard of six years with the apple 'Maxi Gala' grafted on 'M9' rootstock. A randomized complete block design was used with five replicates. Each experimental unit (plot) was formed by a single plant, besides two plants left as edges. During the first crop season (September 2015 to March 2016), the precipitation was $1,376 \mathrm{~mm}$ in a total of 93 days with rain, and in the second crop season (September 2016 to March 2017), it was 1,000 $\mathrm{mm}$ in a total of 63 days with rain. Mean temperature in the first crop season was $18.0^{\circ} \mathrm{C}$, and in the second one it was $17.5^{\circ} \mathrm{C}$ (Embrapa Uva e Vinho, 2017).

Prior to sprouting, in each crop season, three representative branches were selected on each tree in the plots. The total number of clusters were labelled in each branch to determine fruit set, at 70 days after full bloom, and the number of fruit in each cluster was recorded to calculate cluster size.

The treatments consisted of three ATS rates and an untreated control. The tested ATS rates were 1.5, 2.5 , and $3.5 \%$ (weight/volume of water) added of the adjuvant Break Thru at $0.2 \% \mathrm{v} / \mathrm{v}$. The treatments were sprayed with a $\mathrm{CO}_{2}$ backpack sprayer with a full cone nozzle tip until runoff on the leaves. During both years, the treatments were sprayed at once when the trees were at $70 \%$ full bloom.

At harvest, yield was recorded for tree replicates in which fruit of each one were sorted out with an industrial grader equipped with an optical color sorter. Then data were recorded for number of fruit, total weight, and percentage of red color. The number of fruit and the yield of each replicate were divided by the trunk cross-sectional area of each tree, in order to obtain crop load and yield efficiency, respectively. In addition, the number of fruit was divided by the plant yield to obtain the mean fruit weight. Fruit were sorted on three groups of color: 50 to $75 \%, 40$ to $50 \%$, and $<40 \%$ of skin red color. After grading, a subsample of 20 fruit per replicate was collected for physical and chemical analyses of length: diameter ratio, flesh firmness (Newton), total soluble solids ( ${ }^{\circ}$ Brix), number of seed per fruit, and russeting level classified into five groups $-0, \leq 10,10$ to 30,30 to 50 , and $\geq 50 \%$ of the fruit epidermis covered with russet.

Data were subjected to statistical analysis using SAS (SAS Institute Inc., Cary, NC, USA). The effects of ATS rates and years were subjected to the analysis of variance, at $5 \%$ probability, using covariance structures for repeated measures in Proc Mixed. In case of significance, the means were analysed through orthogonal polynomial contrasts, at 5\% probability. When necessary, the percentage data were transformed by arcsine square root $(\operatorname{arcsine} \sqrt{\mathrm{x}} / 100)$ to meet the assumptions of normality and homogeneity of variances of the analysis of variance.

Pesq. agropec. bras., Brasília, v.53, n.10, p.1132-1139, Oct. 2018 DOI: 10.1590/S0100-204X2018001000006 


\section{Results and discussion}

After ATS spraying, fruit set decreased inversely proportional to the rate of blossom thinner application (Table 1). The same pattern was observed with the variable crop load, which decreased according to the enhancement of ATS rate. For fruit set, the rate of ATS was not influenced by the environmental condition at spring, making thinning intensity caused by ATS not to variate yearly, although crop load and yield efficiency varied between years as indicated by the F-test. Both variables were linearly responsive to the rate of ATS, even though the higher rates over thinned the trees. There is no significant interaction of ATS with year, indicating that both sources of variation are independent for these variables. According to Byers (2003), an ideal yield efficiency should be between 1.0 and $1.5 \mathrm{~kg}$ of fruit per $\mathrm{cm}^{2}$ in the United States, to maintain fruit with good storability, market appeal, and profitability. In the present study, the elevation of the rates of ATS reduced the yield efficiency below the values indicated by the author.

Similar results and trends for crop load and fruit set were reported, with ATS at rates from 0.5 to $1.5 \%$ that had a linear thinning response according to the concentration when sprayed at bloom (Bound \& Wilson, 2007). Many authors suggest that ATS from 1 to $2 \%$ is effective to reduce crop load at a level that produces good marketable fruit, while higher rates overthin several apple cultivars (Basak, 2006; Bound \& Wilson, 2007; Milić et al., 2011). Based on the crop load data in this experiment, during the first crop season, it is unlikely that ATS $1.5 \%$ was effective to reduce crop load, which was the same found in the untreated control, whereas ATS at 2.5 and $3.5 \%$ were to some extent similar. Thereby, ATS at $2.5 \%$ was more effective to adjust crop load to desirable levels. Moreover, on the second crop season, ATS at $1.5 \%$ exhibited a similar effect as at $2.5 \%$. Crop load and fruit set showed over thinning at 3.5\%, making this rate unsafe in the Southern Brazil conditions.

Cluster size in 2015/2016 with single and double fruit showed a quadratic response to ATS application, in which ATS at 3.5\% promoted more single-fruit clusters than ATS at 1.5 and $2.5 \%$ (Table 2). While double-fruit clusters were more prominent at 1.5 and $2.5 \%$, ATS decreased the number of single fruit and increased the number of double ones. On the second crop season, no ATS effect was observed, according to the orthogonal polynomial contrast. Based on the F-test considering both years, ATS increased the percentage of single-fruit clusters. Double-fruit clusters showed an year-dependent effect of ATS. These results agree with those by Hampson \& Bedford (2011), in which on a two-year experiment ATS at 1.6\% had a variable effect of inducing single-fruit clusters, and significantly induced the predominance of both single- and double-fruit clusters, in comparison to a single-fruit cluster from the control with hand-thinned blossom. Single-fruit clusters are prone to produce fruit up to $6 \mathrm{~g}$ heavier in 'Gala' apples (Link, 2000) and significantly heavier in 'Ambrosia' apple than in doubles or triples (Hampson \& Bedford, 2011).

Table 1. Effect of ammonium thiosulfate (ATS) on fruit set, crop load, and yield efficiency of 'Maxi Gala' apple trees.

\begin{tabular}{|c|c|c|c|c|c|c|}
\hline \multirow{2}{*}{$\begin{array}{l}\text { ATS rate } \\
(\%)\end{array}$} & \multicolumn{2}{|c|}{ Fruit set $(\%)$} & \multicolumn{2}{|c|}{ Crop load (fruit number $\mathrm{cm}^{-2} \mathrm{TCSA}$ ) } & \multicolumn{2}{|c|}{ Yield efficiency $\left(\mathrm{kg} \mathrm{cm}^{-2} \mathrm{TCSA}\right)$} \\
\hline & $2015 / 2016$ & $2016 / 2017$ & $2015 / 2016$ & $2016 / 2017$ & $2015 / 2016$ & $2016 / 2017$ \\
\hline 0 & 14 & 16 & 12.00 & 7.58 & 1.36 & 1.01 \\
\hline 1.5 & 10 & 9 & 12.00 & 4.26 & 1.23 & 0.71 \\
\hline 2.5 & 8 & 6 & 7.96 & 4.57 & 1.00 & 0.75 \\
\hline 3.5 & 6 & 4 & 7.07 & 2.79 & 0.81 & 0.44 \\
\hline Linear & $* *$ & $* * *$ & $* *$ & $* * *$ & $* *$ & $* * *$ \\
\hline Quadratic & $\mathrm{ns}$ & ns & $\mathrm{ns}$ & $\mathrm{ns}$ & $\mathrm{ns}$ & $\mathrm{ns}$ \\
\hline Coefficient of variation (\%) & 34.95 & 32.75 & 23.18 & 29.88 & 21.89 & 26.83 \\
\hline \multicolumn{7}{|c|}{ F-test } \\
\hline ATS & \multicolumn{2}{|c|}{$* * *$} & \multicolumn{2}{|c|}{$* * *$} & \multicolumn{2}{|c|}{$* * *$} \\
\hline Season & \multicolumn{2}{|c|}{$\mathrm{ns}$} & \multicolumn{2}{|c|}{$* * *$} & \multicolumn{2}{|c|}{$* * *$} \\
\hline ATS x Season & \multicolumn{2}{|c|}{ ns } & \multicolumn{2}{|c|}{$\mathrm{ns}$} & \multicolumn{2}{|c|}{$\mathrm{ns}$} \\
\hline
\end{tabular}

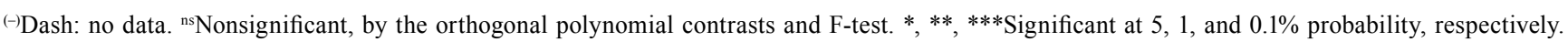
TCSA, trunk cross-sectional area. 
In the first year, the reduction of single-cluster size might have taken place due to insufficient time from the spraying to the effective pollination of the king flowers, while at the second year this timing was respected, indicating that ATS application should be done after the king flowers are fully pollinized. In 'Elstar' apples, pollen tube is required to have grown at least $80 \%$ to reach the ovary to form fruit; when ATS is sprayed in pollen tube with $50 \%$ growth, there is a $50 \%$ probability of fertilization, and it can take 49 to 95 hours for $100 \%$ pollen tube growth, depending on the weather conditions (Maas, 2016).

For fruit weight, ATS expressed a linear effect of increasing fruit weight as the rate was increased, in the first year; however, in the following year, the response was quadratic, with less weight gain at the highest ATS rate (Table 3). Flesh firmness was not affected by ATS in the first season, and at the second season, it showed a quadratic response. Additionally, in the second year, flesh firmness was inversely proportional to fruit weight. The F-test confirms that the effect of ATS varies along the years for fruit weight. These results agree with those by De Salvador et al. (2006), who concluded that in 'Golden Delicious' and 'Red Chief' apples, heavy crop loads lead to lighter fruit, but with high-flesh firmness.

Caustic blossom thinners have a second indirect mode of action as a thinning agent by affecting leaf-stomatal conductance and diminishing photosynthetic rate, which can last over 30 days after the treatment with LS, and it is linear with the elevation of rate and timing, which in turn might be involved in the trade-off between elevated rates of caustic thinners and lag in fruit development (McArtney et al., 2006). Another point to consider is that at bloom, leaves are still developing, have a thin cuticle, and are consequently more susceptible to injury caused by caustic thinners. In sweet cherry, ATS affected leafnet carbon exchange rate up to 17 days until the leaves fully recovered. Caustic thinners increase the chlorophyll fluorescence, indicating that damage occurs in the light harvesting complex of the photosystem II, leading to dissipation of electrons through nonphotochemical processes, in addition to the reduction of chlorophyll content up to seven days to recover (Lenahan \& Whiting, 2006, 2008).

Fruit shape (length:diameter ratio) was not altered by ATS and, in our trial, a highly significant effect of year was found, and there was a significant difference for fruit shape caused by season as shown by the F-test (Table 3). These results agree with those by Bound \& Wilson (2007), in which no difference for fruit shape was found for any rate of ATS (0.5 to $1.5 \%$ ). Fruit shape can be influenced by sunlight exposure throughout the season, which promotes more elongated 'Golden Delicious' apple, in comparison to a more shaded environment (Noè \& Eccher, 1996). In cloudy crop seasons, the denser atmosphere filters a part of the photosynthetic active radiation, which increases the proportion of ultraviolet radiation, and reduces the biosynthesis of endogenous gibberellins,

Table 2. Effects of ammonium thiosulfate (ATS) on the cluster size of 'Maxi Gala' apple trees.

\begin{tabular}{|c|c|c|c|c|c|c|}
\hline \multirow{3}{*}{$\begin{array}{l}\text { Rate of ATS } \\
\text { (\%) }\end{array}$} & \multicolumn{6}{|c|}{ Cluster size } \\
\hline & \multicolumn{2}{|c|}{ Single $(\%)$} & \multicolumn{2}{|c|}{ Double $(\%)^{(1)}$} & \multicolumn{2}{|c|}{ Triple or more $(\%)^{(1)}$} \\
\hline & $2015 / 2016$ & $2016 / 2017$ & $2015 / 2016$ & $2016 / 2017$ & $2015 / 2016$ & $2016 / 2017$ \\
\hline 0 & 87.5 & 74.2 & 10.0 & 24.8 & 2.5 & 1.0 \\
\hline 1.5 & 67.1 & 64.8 & 26.6 & 26.0 & 6.3 & 9.2 \\
\hline 2.5 & 60.1 & 75.4 & 29.2 & 19.4 & 10.7 & 5.4 \\
\hline 3.5 & 70.2 & 59.2 & 23.7 & 31.8 & 6.1 & 9.0 \\
\hline Linear & $* *$ & ns & $* *$ & ns & $\mathrm{ns}$ & ns \\
\hline Quadratic & ** & $\mathrm{ns}$ & * & ns & $\mathrm{ns}$ & ns \\
\hline \multirow[t]{2}{*}{ Coefficient of variation (\%) } & 12.11 & - & 27.14 & - & - & - \\
\hline & \multicolumn{6}{|c|}{ F-test } \\
\hline ATS & \multicolumn{2}{|c|}{$*$} & \multicolumn{2}{|c|}{ ns } & \multicolumn{2}{|c|}{ ns } \\
\hline Season & \multicolumn{2}{|c|}{$\mathrm{ns}$} & \multicolumn{2}{|c|}{ ns } & \multicolumn{2}{|c|}{ ns } \\
\hline ATS x Season & \multicolumn{2}{|c|}{ ns } & \multicolumn{2}{|c|}{$*$} & \multicolumn{2}{|c|}{ ns } \\
\hline
\end{tabular}

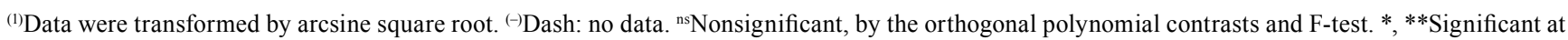
5 and $1 \%$ probability, respectively. 
as it is modulated by light perception (phytochromes), leading to a reduction of cell elongation, which results in flattened fruit, increasing the likelihood of russeting (Hajnajari \& Eccher, 2006).

ATS affected total soluble solids (TSS) of fruit only in the second year, by increasing linearly with the rate. TSS was also affected by the weather conditions of the crop year, showing greater means at the second season as shown by the F-test. Bound \& Wilson (2007) reported a TSS increase when ATS rate was increased. Similar results were found by Meland (2009), who reported a both TSS and fruit weight decreases when crop load increased in 'Elstar' apple.

Seed number had a linear increase with the increment of ATS rate in the first season, and a linear decrease with increased ATS rate in the second season (Table 3). The effect of ATS on seed number is dependent on weather conditions annually. These results differ from those reported by Bound \& Wilson (2007), whose experiment showed that ATS did not affect seed number in 'Hi-Early Delicious' apple. Additionally, McArtney et al. (2006) stated that caustic thinners eventually shrink the number of fertilized ovules, which in turn could reduce seed number. Seed number in apple fruit is an important indicator of fruit quality, as it is strongly related to fruit shape and weight (Buccheri \& Di Vaio, 2004; Garratt et al., 2014). Therefore, fruit with a higher number of seeds lead toward a heavier fruit, as observed in this experiment in the second year, when fruit weigh showed a quadratic response, and mean seed number was lesser than that in the previous crop season.

Skin russeting of apple fruit in the first year was more pronounced especially in the class $\leq 10 \%$, in the first season, with a high increment, although this level of russeting does not compromise the marketable value of fruit. In the second season, there was some occurrence of russeting in the classes from 10 to $30 \%$ and, in both cases, a quadratic effect was significant, with more fruit showing russeting at the rate of 3.5\% in the first year, and of 1.5 and $2.5 \%$ in the second year that induced more russeting. However, this phenomenon was caused by year effect rather than ATS as shown by the F-test (Table 4). Apple fruits are more susceptible to skin russet at early stages, when fruitlets are growing at the highest rate, creating an elevated strain in the cuticle (Hajnajari \& Eccher, 2006).

Fruit was not affected by ATS for red color from 50 to $75 \%$, but by season, as shown by the F-test (Table 5). In the red color group from 40 to $50 \%$, there was a quadratic effect of ATS in which it decreased the percentage of fruits at the rates 1.5 and $2.5 \%$, being the unfavourable weather condition of the first season the responsible for enhancing the percentage of fruits with less color. In a less favorable year (less sunlight), ATS was effective only at the elevated rate to promote color. In the red color group of $<40 \%$, in both crop seasons, the trend inversely followed the pattern of the red color group from 40 to $50 \%$, in which ATS at 1.5 and $2.5 \%$ increased the amount of fruit of this class of

Table 3. Effect of ammonium thiosulfate (ATS) on fruit weight, length:diameter ratio, flesh firmness, total soluble solids, and seed number of 'Maxi Gala' apples.

\begin{tabular}{|c|c|c|c|c|c|c|c|c|c|c|}
\hline \multirow{2}{*}{$\begin{array}{l}\text { Rate of ATS } \\
(\%)\end{array}$} & \multicolumn{2}{|c|}{ Fruit weight $(\mathrm{g})$} & \multicolumn{2}{|c|}{ Length: diameter } & \multicolumn{2}{|c|}{ Flesh firmness (Newton) } & \multicolumn{2}{|c|}{ Total soluble solids $\left({ }^{\circ} \mathrm{Brix}\right)$} & \multicolumn{2}{|c|}{ Seed number } \\
\hline & $2015 / 2016$ & $2016 / 2017$ & $2015 / 2016$ & $2016 / 2017$ & $2015 / 2016$ & $2016 / 2017$ & $2015 / 2016$ & $2016 / 2017$ & $2015 / 2016$ & $2016 / 2017$ \\
\hline 0 & 107 & 134 & 0.93 & 0.95 & 77.44 & 87.58 & 11.30 & 13.12 & 5.55 & 7.09 \\
\hline 1.5 & 110 & 167 & 0.94 & 0.97 & 75.70 & 86.15 & 10.90 & 14.00 & 5.68 & 6.64 \\
\hline 2.5 & 115 & 166 & 0.93 & 0.96 & 75.88 & 84.78 & 11.00 & 13.64 & 7.03 & 5.38 \\
\hline 3.5 & 119 & 159 & 0.93 & 0.95 & 75.35 & 87.40 & 11.01 & 14.28 & 6.16 & 5.43 \\
\hline Linear & $* *$ & $* * *$ & ns & ns & ns & ns & ns & $*$ & $* *$ & $* * *$ \\
\hline Quadratic & $\mathrm{ns}$ & $* * *$ & $\mathrm{~ns}$ & $\mathrm{~ns}$ & ns & $*$ & $\mathrm{~ns}$ & $\mathrm{~ns}$ & $\mathrm{~ns}$ & ns \\
\hline \multirow[t]{2}{*}{ CV (\%) } & 6.04 & 5.21 & - & - & 7.27 & 5.78 & - & 5.24 & 35.80 & 34.84 \\
\hline & \multicolumn{10}{|c|}{ F-test } \\
\hline ATS & \multicolumn{2}{|c|}{$* * *$} & \multicolumn{2}{|c|}{$\mathrm{ns}$} & \multicolumn{2}{|c|}{ ns } & \multicolumn{2}{|c|}{$\mathrm{ns}$} & \multicolumn{2}{|c|}{ ns } \\
\hline Season & \multicolumn{2}{|c|}{$* * *$} & \multicolumn{2}{|c|}{$* * *$} & \multicolumn{2}{|c|}{$* * *$} & \multicolumn{2}{|c|}{$* * *$} & \multicolumn{2}{|c|}{$\mathrm{ns}$} \\
\hline ATS x Season & \multicolumn{2}{|c|}{$* * *$} & \multicolumn{2}{|c|}{$\mathrm{ns}$} & \multicolumn{2}{|c|}{ ns } & \multicolumn{2}{|c|}{ ns } & \multicolumn{2}{|c|}{$* * *$} \\
\hline
\end{tabular}

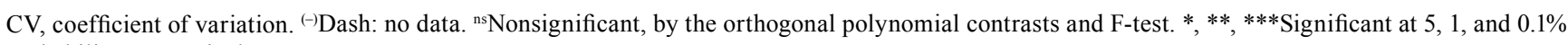
probability, respectively. 
color, according to the orthogonal polynomial contrast. ATS showed some effect by slightly increasing the percentage of fruit with less red color. Even though, in the other groups, the variable was influenced by weather conditions rather than ATS. There is a high positive correlation between fruit color and crop load where decreasing the latter, there is an increment in the trend to enhance red color of apples and European plums (Link, 2000; Meland, 2007, 2009). Anthocyanin biosynthesis is highly dependent on light, temperature, and TSS levels. In an environment with low light and elevated temperature, most of the sucrose is consumed through respiration, while at lower temperatures and high luminosity there is more sucrose available, which leads to elevated TSS and enhanced anthocyanin biosynthesis in apples (Shü et al., 2001).

Table 4. Effect of ammonium thiosulfate (ATS) on the russeting occurrence on 'Maxi Gala' apples skin in the 2015/2016 and 2016/2017 crop seasons.

\begin{tabular}{|c|c|c|c|c|c|c|c|c|c|c|}
\hline \multirow{3}{*}{$\begin{array}{l}\text { Rate of ATS } \\
(\%)\end{array}$} & \multicolumn{10}{|c|}{ Russeting on 'Maxi Gala' apples } \\
\hline & \multicolumn{2}{|c|}{$0 \%$} & \multicolumn{2}{|c|}{$\leq 10 \%$} & \multicolumn{2}{|c|}{10 to $30 \%$} & \multicolumn{2}{|c|}{30 to $50 \%^{(1)}$} & \multicolumn{2}{|c|}{$\geq 50 \%{ }^{(1)}$} \\
\hline & $2015 / 2016$ & $2016 / 2017$ & $2015 / 2016$ & $2016 / 2017$ & $2015 / 2016$ & $2016 / 2017$ & $2015 / 2016$ & $2016 / 2017$ & $2015 / 2016$ & $2016 / 2017$ \\
\hline$\overline{0}$ & 27.0 & 64.0 & 40.5 & 34.0 & 25.0 & 2.0 & 7.0 & 0 & 0.5 & 0 \\
\hline 1.5 & 29.1 & 36.0 & 39.3 & 48.0 & 20.2 & 16.0 & 8.0 & 0 & 3.4 & 0 \\
\hline 2.5 & 30.3 & 41.4 & 34.8 & 42.6 & 23.8 & 16.2 & 8.6 & 0 & 2.6 & 0 \\
\hline 3.5 & 28.6 & 41.0 & 48.1 & 50.0 & 20.0 & 9.0 & 7.0 & 0 & 0.5 & 0 \\
\hline Linear & ns & ns & ns & ns & ns & ns & ns & - & ns & - \\
\hline Quadratic & ns & ns & $*$ & ns & $\mathrm{ns}$ & $* *$ & $\mathrm{~ns}$ & - & $\mathrm{ns}$ & - \\
\hline \multirow[t]{2}{*}{ CV (\%) } & - & - & 28.25 & - & - & 37.32 & - & - & - & - \\
\hline & \multicolumn{10}{|c|}{ F-test } \\
\hline ATS & \multicolumn{2}{|c|}{$\mathrm{ns}$} & \multicolumn{2}{|c|}{ ns } & \multicolumn{2}{|c|}{$\mathrm{ns}$} & \multicolumn{2}{|c|}{$\mathrm{ns}$} & \multicolumn{2}{|c|}{$\mathrm{ns}$} \\
\hline Season & \multicolumn{2}{|c|}{$* *$} & \multicolumn{2}{|c|}{ ns } & \multicolumn{2}{|c|}{$* * *$} & \multicolumn{2}{|c|}{$* * *$} & \multicolumn{2}{|c|}{$*$} \\
\hline ATS x Season & \multicolumn{2}{|c|}{ ns } & \multicolumn{2}{|c|}{ ns } & \multicolumn{2}{|c|}{ ns } & \multicolumn{2}{|c|}{ ns } & \multicolumn{2}{|c|}{ ns } \\
\hline
\end{tabular}

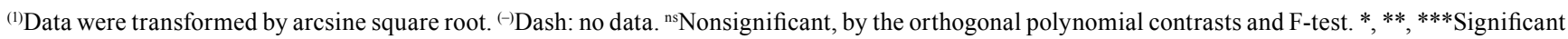
at 5,1 , and $0.1 \%$ probability, respectively. $\mathrm{CV}$, coefficient of variation.

Table 5. Effect of Ammonium thiosulfate (ATS) on the percentage of red color on 'Maxi Gala' apple skin in the 2015/2016 and 2016/2017 crop seasons.

\begin{tabular}{|c|c|c|c|c|c|c|}
\hline \multirow{3}{*}{$\begin{array}{l}\text { Rate of ATS } \\
(\%)\end{array}$} & \multicolumn{6}{|c|}{ Red color on 'Maxi Gala' apple skin } \\
\hline & \multicolumn{2}{|c|}{50 to $75 \%^{(1)}$} & \multicolumn{2}{|c|}{40 to $50 \%$} & \multicolumn{2}{|c|}{$<40 \%^{(1)}$} \\
\hline & $2015 / 2016$ & $2016 / 2017$ & $2015 / 2016$ & $2016 / 2017$ & $2015 / 2016$ & $2016 / 2017$ \\
\hline 0 & 6.4 & 71.8 & 64.4 & 26.0 & 29.8 & 2.8 \\
\hline 1.5 & 9.4 & 65.2 & 44.0 & 31.0 & 46.8 & 4.2 \\
\hline 2.5 & 4.6 & 65.8 & 51.6 & 29.8 & 43.8 & 4.6 \\
\hline 3.5 & 19.2 & 79.6 & 58.8 & 17.0 & 22.0 & 3.4 \\
\hline Linear & ns & $\mathrm{ns}$ & ns & ns & ns & ns \\
\hline Quadratic & $\mathrm{ns}$ & $\mathrm{ns}$ & $* *$ & ns & $* *$ & $*$ \\
\hline \multirow[t]{2}{*}{ Coefficient of variation (\%) } & - & - & 19.18 & - & 21.50 & 18.38 \\
\hline & \multicolumn{6}{|c|}{ F-test } \\
\hline ATS & \multicolumn{2}{|c|}{ ns } & \multicolumn{2}{|c|}{$\mathrm{ns}$} & \multicolumn{2}{|c|}{$* * *$} \\
\hline Season & \multicolumn{2}{|c|}{$* * *$} & \multicolumn{2}{|c|}{$* * *$} & \multicolumn{2}{|c|}{$* * *$} \\
\hline ATS x Season & \multicolumn{2}{|c|}{ ns } & \multicolumn{2}{|c|}{$\mathrm{ns}$} & \multicolumn{2}{|c|}{ ns } \\
\hline
\end{tabular}

${ }^{(1)}$ Data were transformed by arcsine square root. ${ }^{(-)}$Dash: no data. ${ }^{\mathrm{n}}$ Nonsignificant, by the orthogonal polynomial contrasts and $\mathrm{F}-$ test. $*, * *, * * *$ Significant at 5,1 , and $0.1 \%$ probability, respectively. 


\section{Conclusions}

1. Ammonium thiosulfate spray at $2.5 \%$ is effective to reduce crop load and to improve fruit quality in 'Maxi Gala' apples (Malus domestica).

2. The thinning effect of ammonium thiosulfate on 'Maxi Gala' apples is not dependent on the weather conditions during the crop season.

3. High rates of ammonium thiosulfate cause overthinning on 'Maxi Gala' apples trees and is not associated with improved fruit quality.

\section{Acknowledgments}

To Coordenação de Pessoal de Nível Superior (Capes), for scholarship grant; and to Conselho Nacional de Desenvolvimento Científico e Tecnológico (CNPq), for financial support.

\section{References}

AGROFIT: Sistema de Agrotóxicos Fitossanitários. Consulta de produtos formulados. Available at: $<\mathrm{http}$ ://agrofit.agricultura. gov.br/agrofit_cons/principal_agrofit_cons>. Accessed on: Aug 162017.

ANUÁRIO BRASILEIRO DA MAÇÃ. Santa Cruz do Sul: Gazeta, 2016. 64p.

BASAK, A. The effect of fruitlet thinning on fruit quality parameters in the apple cultivar 'Gala'. Journal of Fruit and Ornamental Plant Research, v.14, p.143-150, 2006. Supplement 2.

BOUND, S.A.; WILSON, S.J. Ammonium thiosulfate and 6-benzyladenine improve the crop load and fruit quality of 'Delicious' apples. Australian Journal of Experimental Agriculture, v.47, p.635-644, 2007. DOI: 10.1071/EA05217.

BUCCHERI, M.; DI VAIO, C. Relationship among seed number, quality, and calcium content in apple fruits. Journal of Plant Nutrition, v.27, p.1735-1746, 2004. DOI: 10.1081/PLN200026409.

BYERS, R.E. Flower and fruit thinning and vegetative: fruiting balance. In: FERREE, D.C., WARRINGTON, I.J. (Ed.). Apples: botany, production and uses. [Wallingford]: Cabi, 2003. p.409430. DOI: $10.1079 / 9780851995922.0409$.

DE SALVADOR, F.R.; FISICHELLA, M.; FONTANARI, M. Correlations between fruit size and fruit quality in apple trees with high and standard crop load levels. Journal of Fruit and Ornamental Plant Research, v.14, p.113-122, 2006. Supplement 2.

EMBRAPA UVA E VINHO. Agrometeorologia - Vacaria/RS. Bento Gonçalves, 2017. Available at: <https://www.embrapa.br/ uva-e-vinho/dados-meteorologicos/vacaria/-/asset_publisher/ tCP65NY3GITd/content/boletim-meteorologico-vacaria- maio-2016/1355300 inheritRedirect $=$ false $\&$ redirect $=$ https $\% 3 \mathrm{~A} \% 2 \mathrm{~F} \% 2 \mathrm{Fw} w$ w.embrapa.br\%2Fuva-e-vinho\%2Fdadosmeteorologicos\%2Fvacaria\%3Fp_p_id\%3D101_INSTANCE_ tCP65NY3GITd\%26p_p_lifecycle\%3D 0\%26p_p state\%3Dnormal\%26p_p_mode $\% 3$ Dview\%26p_p_col_ id $\% 3$ Dcolumn-2\%26p_p_col_pos\%3D3\%26p_p_col_ count\%3D7>. Accessed on: Dec 192017.

GARRATT, M.P.D.; BREEZE, T.D.; JENNER, N.; POLCE, C.; BIESMEIJER, J.C.; POTTS, S.G. Avoiding a bad apple: insect pollination enhances fruit quality and economic value. Agriculture, Ecosystems and Environment, v.184, p.34-40, 2014. DOI: 10.1016/j.agee.2013.10.032.

GREENE, D.W. Chemicals, timing, and environmental factors involved in thinner efficacy on apple. HortScience, v.37, p.477481, 2002.

HAJNAJARI, H.; ECCHER, T. Light spectrum affects growth and endogenous gas content of in vitro growth apple shoots. Acta Horticulturae, v.727, p.37-43, 2006.

HAMPSON, C.; BEDFORD, K. Efficacy of blossom thinning treatments to reduce fruit set and increase fruit size of Ambrosia and Aurora Golden Gala ${ }^{\text {tm }}$ apples. Canadian Journal of Plant Science, v.91, p.983-990, 2011. DOI: 10.4141/cjps2011-070.

JAKOPIC, J.; ZUPAN, A.; ELER, K.; SCHMITZER, V.; STAMPAR, F.; VEBERIC, R. It's great to be the King: Apple fruit development affected by the position in the cluster. Scientia Horticulturae, v.194, p.18-25, 2015. DOI: 10.1016/j. scienta.2015.08.003.

LAKSO, A.N.; GOFFINET, M.C. Apple fruit growth. New York Quarterly, v.21, p.11-14, 2013.

LENAHAN, O.M.; WHITING, M.D. Chemical thinners reduce sweet cherry net $\mathrm{CO}_{2}$ exchange, stomatal conductance and chlorophyll fluorescence. Acta Horticulturae, v.795, p.681-684, 2008.

LENAHAN, O.M.; WHITING, M.D. Physiological and horticultural effects of sweet cherry chemical blossom thinners. HortScience, v.41, p.1547-1551, 2006.

LINK, H. Significance of flower and fruit thinning on fruit quality. Plant Growth Regulation, v.31, p.17-26, 2000. DOI: 10.1023/A:1006334110068.

MAAS, F.M. Control of fruit set in apple by ATS requires accurate timing of ATS application. Acta Horticulturae, v.1138, p.45-51, 2016. DOI: 10.17660/ActaHortic.2016.1138.6.

MCARTNEY, S.; PALMER, J.; DAVIES, S.; SEYMOUR, S. Effects of lime sulfur and fish oil on pollen tube growth, leaf photosynthesis and fruit set in apple. HortScience, v.41, p.357360, 2006.

MELAND, M. Effects of different crop loads and thinning times on yield, fruit quality, and return bloom in Malus domestica Borkh. 'Elstar'. The Journal of Horticultural Science and Biotechnology, v.84, p.117-121, 2009. DOI: 10.1080/14620316.2009.11512607.

MELAND, M. Efficacy of chemical bloom thinning agents to European plums. Acta Agriculturae Scandinavica, v.57, p.235242, 2007. DOI: 10.1080/09064710600914236. 
MILIĆ, B.; MAGAZIN, N.; KESEROVIĆ, Z.; DORIĆ, M. Flower thinning of apple cultivar Braeburn using ammonium and potassium thiosulfate - short communication. Horticultural Science, v.38, p.120-124, 2011. DOI: 10.17221/57/2011-HORTSCI.

MYRA, M.T.; EMBREE, C.G.; GOOD-AVILA, S.V.; MORTON, V.K. Assessment of potential organic pollenicides as apple blossom thinners. International Journal of Fruit Science, v.6, p.35-52, 2007. DOI: 10.1300/J492v06n03_04.
NOĖ, N.; ECCHER, T. 'Golden Delicious' apple fruit shape and russeting are affected by light conditions. Scientia Horticulturae, v.65, p.209-213, 1996. DOI: 10.1016/0304-4238(95)00850-0.

SHÜ, Z.-H.; CHU, C.-C.; HWANG, L.-J.; SHIEH, C.-S. Light, temperature, and sucrose affect color, diameter, and soluble solids of disks of wax apple fruit skin. HortScience, v.36, p.279-281, 2001.

Received on August 16, 2017 and accepted on March 27, 2018 